\title{
EXPLORING STUDENTS' LEARNING STRATEGIES AND GENDER DIFFERENCES IN ENGLISH LANGUAGE TEACHING
}

\author{
Murni Mahmud \\ Universitas Negeri Makassar, Indonesia \\ Email: murnimahmud@unm.ac.id \\ Sahril Nur \\ Universitas Negeri Makassar, Indonesia \\ E-mail: sahril@gmail.com \\ DOI: $10.26858 /$ ijole.v2i1.4346
}

\begin{abstract}
The main objective of this paper is to explore the learning strategies of male and female students and to discuss those strategies in relation to gender differences. This research was conducted in one senior high school in Makassar, Indonesia. The number of respondents was 71 students taken randomly by using Slovin formula among 250 students. The study used quantitative and qualitative data. The quantitative data were collected by using a questionnaire of SILL whereas the qualitative data were taken by using interview. The learning strategies were discussed based on Oxford's learning strategies (1990) whereas the notion of gender differences in relation to learning strategies was discussed in the framework of gender differences in communication proposed by Lakoff $(1975,1976)$ and (Tannen, 1990, 1994). Findings from the questionnaire show that female students use cognitive, compensation, and affective strategy more often compared to male students while male students use memory, metacognitive, and social strategy more often compared to female students. Findings from the interview show that female and male students chose different learning strategies. In addition, those learning strategies were influenced by the notion of gender differences in communication. These findings significantly give beneficial inputs to the process of English language teaching in order to create effective teaching and classroom interaction. It also provides significant contribution to the study on language and gender in communication in a setting of education and language teaching.
\end{abstract}

Keywords: male students, female students, gender, gender differences, learning strategies, English language teaching.

\section{INTRODUCTION}

The teaching of English as a foreign language nowadays still becomes important discussions among English language practitioners, especially in an effort to create effective process of English language teaching. Studies had been conducted in order to know the effectiveness of teachers and students' roles in the class (Rahimi \& Hosseini Karkami, 2015; Soodmand Afshar, \& Doosti, 2014; Mahmud, 2017, 2018). Gender issues in relation to English language teaching, have also been investigated recently (Mahmud, 2010; Roohani \& Zarei, 2013; Viriya \&
Sapsirin, 2014). Many other studies had revealed the complicated problems faced by English learners in learning English (Serag, 2011; Krashen, 2013).

One of the factors in English language teaching which need to be taken into account is about learning strategies. Studies conducted by scholars (Kato, 2005, 2009; Li, 2005; Oxford, 1989, 1990, 1996; Oxford \& Burry-Stock, 1995; Oxford \& Nyikos, 1989; Wang, 2009, Cabaysa, 2010; Khmakhien, 2012; Tam, 2013, \& Hassan, 2017) emphasized that learning strategies are important factors in teaching and learning process. In order to be successful, 
language learners need to know, master, and create language learning strategies that are mostly appropriate to use. English teachers should also make every effort to encourage the use of learning strategies that can transform English classrooms into communicative practices.

One learning strategy cannot be used by all students although those learning strategies are considered effective or efficient. Problems may be due to personal problems and any other factors, including gender differences. Park \& French (2011, p. 177), for example, state that studies investigating gender differences in learning strategy research is crucial because men and women are considered to be different in educational and occupational outcomes in general. An example of study was conducted by Puteh, Zin, \& Ismail (2016), which confirmed that gender differences need to be given attention since "the difference between the girls and boys has been attributed to reading engagement among the students ( $p$. 118). Therefore, gender differences are assumed to influence the choices of those learning strategies (Ehrman \& Oxford, 1989; Oxford, 1990; Gurian, 2001; Severiens \& Dam, 2005; Zhenhui, 2005; Logan \& Johnston, 2009; Yilmaz, 2010; Park \& French, 2011; Roohani \& Zarei, 2013; Tam, 2013; Viriya \& Sapsirin, 2014).

This facts shows that gender issues hold important roles in human's life. Gender is also an important part of communication. When communicating to each other, interactions may take place between men and women, and of course, relations between men and women may influence their communicative styles. Giles (2008) has noted that gender is an important aspect influencing communication strategies of people besides other factors such as ethnicity, occupational status, and age. As a result, many scholars had made gender issues as the area of investigations (Keeler, 1990, Kuipers, 1990; Hassan, 2000; Mahmud, 2008; Amir, Abidin, Darus, \& Ismail, 2012; Mellor \& Fung, 2012;
Koeser \& Sczesny, 2014; Ali \& Krish, 2016, Anshori, 2016; Aziz, Jin, \& Nordin, 2016, and Seyyedrezaie \& Vahedi, 2017).

Gender differences in communication had become important topics for discussion recently since the notion of "women's language" was elaborated by Lakoff (1975, 1976) and followed by Tannen (1990, 1994). This notion emphasized that men and women have different strategies in communication. An example was a study on sex roles in Malaysian perspectives by Mellor and Fung (2012, p. 98). This study confirmed that women have higher empathy than men whereas men are less forgiving. Another study was conducted by Mahmud (2008) in Bugis society, Indonesia. Mahmud found some characteristics of men and women in Bugis society in using a language. One of the examples is the tendency of women to use polite forms, to express opinions emotionally, to talk about their own achievement and the weakness of other people. Another study shows the differences between females and males in using the function words, neologisms/blog words as well as use of tag questions and adverbs initiating sentences (Ali \& Krish, 2016, p. 21). Keong, Gill, Noorezam, and Abdulrazak (2012) also found that there are gender differences identified in terms of emoticons, onomatopoeic and word length in the use of SMS among Malay university students.

This facts shows that the area of education, especially English language teaching, is one of the potential areas to observe the relationship of gender differences in communication. Studies conducted by many scholars (EarlNovell, 2001; Martin \& Marsh, 2005; Zhenhui, 2005; Lee \& Collins, 2008; Wang, 2009; Mahmud, 2010; Yilmaz, 2010; Burck, 2011; Božinovi, 2011; Park \& French, 2011; Roohani \& Zarei, 2013; Hassaskhah \& Zamir, 2013; Kobayashi, 2014) had revealed that gender differences should be considered as an important factor in English language teaching. 
For that purpose, the researcher is interested in investigating the choices of learning strategies of students in Makassar senior high schools in relation to gender differences by using a mixed-method of qualitative and quantitative research. Eckert (1998, p. 64) states that gender differences can be found in "different cultures, places, and groups". As one of the big cities in Southeast Indonesia, studies on learning strategies in Makassar in relation to gender differences would bring significant findings. The mixedmethod of qualitative and quantitative method proposed in this study allowed the new phenomena of learning strategies in relation to gender differences in communication.

The first question addressed in this paper is whether female and male students apply different learning strategies. The second question is whether the choices of those learning strategies are affected by gender differences. Discussion in this paper becomes precious findings on the literature of English language teaching, in which it can contribute to the innovation of English language teaching. It will also become valuable results on the discussion of gender differences in communication and its effects on educational setting, particularly in English language teaching.

\section{Gender Differences in Communication}

Tannen (1990) in her book "You Just Don't Understand" has viewed the men and women differences of language style. One example is that there is a tendency for men to use language to "preserve their independence and maintain their position in the group". Conversely, women use language to "create connection and identity". Tannen (1990) indicates male speech as conflictive and female speech as cooperative. Itakuro and Tsui (2004, p. 245) state that "males played a central role in shaping the development of the conversation". Consequently, all the conversation evolved around the interests of the male speakers while the female speakers were forced to play a subservient role to the conversations.

The main focus of their conversation tends to be different. When men and women are interacting, these purposes may have counteracted to each other, leading to different perceptions or opinions. Biber and Burges (2000) confirm that women's focus in conversation is on "personal and interactional aspects of conversation", whereas men's focus is more on "transferring information". Stanton (2001) also states that conversations for women are for the sake of "developing and preserving intimacy", while for men, "maintaining power" is more important than other aspects, such as intimacy.

Tymson (1998, pp. 18-19) further mentions some differences of men and women in their conversations. Typically men will talk about "things", while women will talk about how they feel about "things". It is further stated that men and women have different areas of conversation. Men, for example, like to discuss business, politics, current affairs, cars, sport and of course. Conversely, women like to talk about their relationship, people they know, some current affairs. Gray further (1992, pp. 16-18) states that, "a man's sense of self is defined through his ability to achieve results...women's sense of self is defined through her feelings and the quality of her relationships."

Several characteristics of women's language are mentioned by Lakoff (1976) that women tend to use "lexical hedges or fillers, tag questions, rising intonations, intensifiers, etc". Vanfossen $(2001$, p. 2) also notices the passiveness of women by the use of "tag questions, disclaimers, or directive statements". In addition, there is a tendency for females to use more non-verbal communication than males. Griffin, McGahee, and Slate (1999) state that females used more eye contacts, gestures, and smiles than males (67.5\%, $75.5 \%$, and $83.7 \%$ respectively). 
There are also differences on the views of men and women about conversation. Eckert and McConnel-Ginet (1994, p. 453) note that the language used by women is said to reflect "women's conservatism, prestige consciousness, desire for upward mobility, insecurity, deference, nurture, emotional expressivity, connectedness, sensitivity to others, and solidarity". On the other hand, the language used by men is regarded as "evincing their toughness, lack of affect, competitiveness, independence, competence, hierarchy and control".

\section{Gender Differences in English Language Teaching}

The roles of gender in education have also been recognized recently. Ehrman and Oxford (1989) reported that "women used more learning strategies compared to men". In addition, more women preferred the use of intuition and feeling to sensing and thinking than men. Females are more aware of their use of strategies to facilitate their learning (Oxford, 1990). Men were more likely than women "to prefer the abstract conceptualization mode of learning" (Severiens \& Dam, 2005). According to Younger, Warrington, and Jacquita (1999, p. 325), the interaction of male student and female student are different in which male students tend to "dominate certain classroom interaction" whereas female students "participate more in teacher-student interaction which support learning". Mahmud (2010, p. 182) mentioned that some characteristics of female students such as being ashamed, nervous, not certain, can influence their English proficiency and therefore they prefer writing as the skill to express their ideas whereas for men, their need to "challenge and maintain strength as men" required them to choose speaking as the way to express their ideas.

In terms of language skills, girls had better reading comprehension, read more frequently and had a more positive attitude to reading and school (Logan \& Johnston, 2009). Girls outperformed the boys across all reading aspects and types of reading texts (Puteh, et al, 2016, p. 109). Females performed better than males in first language acquisition (Tam, 2013, p. 23). Nassab and Motlag (2017) found that girls were speaking without any stress and pause. Female learners were speaking without any interruption with so many verbs, adjectives, coordinators, but the boys had so many interruptions during their speech and sometimes their pronunciation and grammar was wrong with more discourse markers.

Gender differences are not only found in terms of students, but also for teachers. Starbuck (2003, p.1) comments that gender is a factor in selecting the strategies by teachers in teaching. Lacey, et al. (1998, cited in Starbuck, 2003 , p. 2) also point out that there are differences in the strategies of female and male teachers in teaching. Accordingly, male teachers tend to be "dominant and exacting" whereas female teachers tend to be "more informal and open to students and their ideas". A study by Sakurai (2012) also proved the influence of gender in students' perception toward good teacher. A study by Mahmud (2015) also found that students' expectations toward their teachers are influenced by gender issues. Students mostly preferred female teachers than male teachers because female teachers are more accommodating than male teachers.

\section{Learning Strategies}

According to Lee (2010, p. 21), learning strategy is "learning skills, learning-to-learn skills, thinking skills, problem skills or, in other words the methods which learners use to intake, store, and retrieve during the learning process". Ellis (1994) also states that strategies are related to "some kind of mental activity or behavior that can occur in a particular phase of the learning and communication process".

Oxford (1989) states that language learning strategies are "behaviors or actions 
which learners use to make language learning more successful, self-directed and enjoyable". Oxford (1990, p. 15) further comprised six categories of learning strategies and classified them into direct and indirect strategies. In direct way, strategies can be in the form of memory (e.g. making associations between new and already known information through use of formula, phrase, verse or the like), cognitive (e.g. making associations between new and already known information, and compensation (e.g. using context to make up for missing information in reading and writing). In indirect way, learning strategies are in the form of metacognitive (e.g. controlling own cognition through the coordination of the planning, organization and evaluation of the learning process), affective strategy (e.g. regulation of emotions, motivation and attitude toward learning), and social strategy (e.g. the interaction with other learners to improve language learning and cultural understanding).

\section{RESEARCH METHOD}

This paper was based on the data taken in 2015. This research took one senior high school in Makassar (SMA 17 Makassar). The school was chosen since it is a favorite school and becomes the top rank school in Makassar. The number of population was 250 students of the second year.

This research was conducted using the mixed-method of quantitative and qualitative design. According to Gay, Mills, and Airasian (2006, p. 490), there are three types of mixed research design. The first model is QUALQuan model, in which qualitative data are collected first and more heavily weighted than quantitative data. The second is QUAN-Qual model. In this model, quantitative data are collected first and more heavily weighted than qualitative data. The third is QUAN-QUAL model known as the triangulation mixed method design, in which quantitative and qualitative data are equally weighted. The researcher used QUAN-Qual model (the second type of mixed methods).

The quantitative data for this research was collected through questionnaire which aimed to find out the frequency of the language learning strategies used by male and female students and to find out the differences between male and female students in the use of language learning strategies. The SILL modified questionnaire (Strategies Inventory of Language Learning) developed by Rebecca Oxford (1990) was used. The questionnaire was distributed to the 72 students consisting of 36 male students and 36 female students in XI grade students of SMA Negeri 17 Makassar. Seventy two (72) students were taken randomly as a sample of 250 students of the total population by using the Slovin formula as follows:

$$
\begin{aligned}
& \frac{N}{1+N^{e 2}} \\
& \frac{250}{1=250\left(0.1^{2}\right)} \\
& \frac{250}{3.5} \\
& \mathrm{n}=72
\end{aligned}
$$

Where: $\mathrm{n}$ (sample size); $\mathrm{N}$ (population size); e (margin of error, $10 \%$ for margin of error where the significance is 0,1 ).

Data from SILL were analyzed descriptively based on Oxford's Learning Strategies including (1) memory strategy, (2) cognitive strategy, (3) compensation strategy, (4) metacognitive strategy, (5) affective strategy and (6) social strategy. The descriptive analysis provides mean differences mean, average, of responses and level category. The one way analysis (ANOVA) procedure was used to see if there is significant difference between male and female students in the use of language learning strategies in reading and speaking. The 0.05 level of statistical significance is used. As a qualitative dimension for this research, a follow-up interview was employed. For this purpose, 12 respondents ( 6 
males and 6 females) were chosen to be interviewed. The twelve respondents were chosen purposively since they got higher scores obtained from SILL. This interview was intended to explore whether their learning strategies were affected by gender differences. The questions were mainly about their preferences in sex to communicate in English, reluctance in speaking with different sex, preferences in expressing opinions, and preferences of being active. Questions were addressed to the respondents individually and recorded. The results of the interview were transcribed and discussed descriptively in relation to gender differences.

\section{FINDINGS}

\section{Learning Strategies from SILL}

This part shows the comparison of females and males students in their learning strategies based on the questionnaire of SILL.
Table 1. Frequency of Learning Strategies of Female and Male Students

\begin{tabular}{llll}
\hline \multirow{2}{*}{ No } & Learning & Strategie: & Frequency \\
\cline { 3 - 4 } & of Oxford (1990) & Female & Male \\
\hline 1 & Memory & 3 & 2 \\
2 & Cognitive & 4 & 2 \\
3 & Compensation & 10 & 11 \\
4 & Metacognitive & 15 & 21 \\
5 & Affective & 3 & 0 \\
6 & Social & 5 & 3 \\
\hline
\end{tabular}

From 36 respondents of male students, metacognitive strategies were also chosen more often than other learning strategies. There were twenty one (21) respondents who chose metacognitive learning strategies. The next strategies preferred by male students were compensation strategy, chosen by 11 (ten) of them. Memory strategy and cognitive were only chosen by two (2) respondents respectively. Social strategy was chosen by 3 (six) respondents whereas affective strategy was not chosen by respondents. This shows that of the six strategies of learning, male respondents also chose mostly metacognitive and compensation strategy (see appendix 1 and 2). To see the different strategies of learning strategies applied by female and male students, the table below shows the mean difference:

Table 2. Mean difference of learning strategies of males and females

\begin{tabular}{llllll}
\hline \multirow{2}{*}{ Memory } & Group & $\mathrm{N}$ & Mean & $\begin{array}{l}\text { Std. } \\
\text { Deviation }\end{array}$ & Std. Error Mean \\
& Female & 36 & 2.97 & .57748 & .09625 \\
\cline { 2 - 6 } Cognitive & Male & $\mathbf{3 6}$ & $\mathbf{3 . 0 3}$ & .61854 & .10309 \\
\hline \multirow{2}{*}{ Compensation } & Female & $\mathbf{3 6}$ & $\mathbf{3 . 3 4}$ & .55162 & .09194 \\
\cline { 2 - 6 } & Male & 36 & 3.23 & .54451 & .09075 \\
\cline { 2 - 6 } Metacognitive & Memale & $\mathbf{3 6}$ & $\mathbf{3 . 3 7}$ & .63392 & .10565 \\
\cline { 2 - 6 } & Female & 36 & 3.33 & .71257 & .11876 \\
\hline \multirow{2}{*}{ Affective } & Male & 36 & 3.69 & .49693 & .08282 \\
\hline Social & Female & $\mathbf{3 6}$ & $\mathbf{3 . 7 0}$ & .71978 & .11996 \\
\cline { 2 - 6 } & Male & $\mathbf{3 6}$ & $\mathbf{3 . 0 8}$ & .57664 & .09611 \\
\hline & Female & 36 & 3.01 & .73689 & .12282 \\
\cline { 2 - 6 } & Male & 36 & 3.20 & .44888 & .07481 \\
\hline
\end{tabular}


Table 2 above shows a difference in the mean scores of female and male students in terms of their learning strategies. In terms of memory strategy, male students outnumbered female students $(3.03>2.97)$. The same case can be seen in metacognitive style and social style, in which the mean score of male students was higher than those of female students $\quad(3.70>3.69$ and 3.22>3.26) respectively. Other learning strategies (cognitive, compensation, and affective) showed the higher scores of female students than male students. In cognitive style, females outnumbered males (3.34>3.23). Female students also chose compensation strategy as their learning strategies more often than their male counterpart (3.37>3.33). The last, affective style was also more preferably chosen by females than males $(3.08>3.01)$. This table shows that there female students outnumbered male students in the use of cognitive, compensation, and affective strategy whereas male students outnumbered female students in the use of memory, metacognitive, and social strategy.

To see whether those differences are significant or not, the one way analysis (ANOVA) procedure used that can be seen in the following table:

Table 3. Independent Sample Test of Male and Female Differences

\begin{tabular}{lllll}
\hline \multirow{2}{*}{ Strategy } & Mean & $\begin{array}{l}\text { Signi } \\
\text { fican- } \\
\text { Male }\end{array}$ & $\begin{array}{l}\text { Fema- } \\
\text { le }\end{array}$ & $\begin{array}{l}\text { Diffe- } \\
\text { rences }\end{array}$ \\
\hline Memory & 3.03 & 2.98 & 0.67 & $>0.05$ \\
Cognitive & 2.23 & 3.35 & 0.37 & $>0.05$ \\
Compensation & 3.33 & 3.38 & 0.77 & $>0.05$ \\
Metacognitive & 3.71 & 3.69 & 0.91 & $>0.05$ \\
Affective & 3.01 & 3.08 & 0.65 & $>0.05$ \\
Social & 3.22 & 3.20 & 0.90 & $>0.05$ \\
\hline
\end{tabular}

Table 4 illustrates that the use of memory strategy, metacognitive strategy, and social strategy is not significantly different between male and female students. The result shows that $0.67>0.05$ for memory strategy, $0.91>$
0.05 for metacognitive strategy, and $0.90>$ 0.05 for social strategy. However, the mean score in the table shows that male students use memory strategy, metacognitive strategy, and social strategy more often compared to female students. For female students, the use of cognitive strategy, compensation strategy, and affective strategy is not significantly different between male and female students. The result shows that $0.37>0.05$ for cognitive strategy, $0.77>0.05$ for compensation strategy, and 0.65 $>0.05$ for affective strategy. However, the mean score in the table shows that female students use cognitive strategy, compensation strategy, and affective strategy more often compared to male students.

The above table shows that there is no statistically significant difference in the learning strategies between female and male in a significant difference. However, female students use cognitive, compensation, and affective strategy more often compared male students in mean score while male students use memory, metacognitive, and social strategy more often compared female students.

\section{Learning Strategies from the Interview}

For the interview, 12 respondents ( 6 males and 6 females) were involved. The first thing to explore is about the preference of the students in choosing their partners in speaking English to communicate. Their reasons can be seen as follows:

\section{Extract 1. Reluctance in Speaking English}

I: $\quad$ "sometimes when speaking English, do you sometimes feel reluctant to speak with the same sex? Do you feel reluctant to speak English with men?"

F2: "no"

I: "no?"

F2: "as long as we are in the same age"

M3: "sometimes"

I: "why sometimes?"

M3: "sometimes I don't have a topic to talk with women" 
From interviews with other respondents in the above, it can be seen that the respondents women and men also have a somewhat different view. Female respondents said that as long as they were at the same age, there would be no problem for him to talk with the different sexes. In contrast, male respondents prefer to speak with the same sex because according to him, he sometimes did not have more ideas when speaking to different sexes. Compare with the extracts of interview as follows:

Extract 2. Reluctance in Speaking English

I: $\quad$ (asking the male respondents) "do you sometimes feel reluctant to speak with women?

M4: "no, because we already know each other"

I: "oh, so if it is already familiar, is that fine?"

M4: "no problem"

I: How about you?

F3: "for example, $f$ we have just known each other, yes, it is reluctant, but if we are already in the same class, no problem"

F4: "for me, with the different sex, I sometimes feel nervous because we do not know each other well"

In extract 2 above, the familiarity and the same age will help them to speak freely in English. Therefore, both male and female students did not mind speaking English with the other sex as long as they had been familiar to them and the same age.

\section{Extract 3. Preferences in Expressing Opinions \\ I: "say for example, you are going to express opinions, which one do you prefer, oral or written?" \\ M5: “ I like speaking” \\ I: "you like speaking?, why?" \\ M5: "Because we can be direct, what we are going to say can be expressed directly" \\ I: "how about writing?"}

M5: "in writing, sometimes, there is something hindering, or I forgot what to say"

I: "How about you?"

F5: "writing"

I: "oh writing, why?"

F5: "If in writing, we can think about the mistakes, if there is something wrong, we can revise"

From the extract of interview above, it can be seen that both of the respondents above had different way of expressing their opinions. The female respondent preferred to express her opinion by writing because she could not express directly and of course, she was wondering a lot about the mistakes. If she expressed her opinion in speaking she might have time to correct the mistakes. In writing, she would have a lot of chance to correct her mistakes. Different from the female respondent, the male respondent preferred to express his opinion by speaking. The main reason was that he likes to be direct. He said that by speaking he could direct his opinion. Through writing he sometimes found obstacles hindering him such as forgetting the idea.

The next question is about the preferences to be active in the class. The male and female respondents were asked about the way to choose to learn in the English class, whether to be active or to be just passive. From the six male respondents and six female respondents, all of the male respondents chose to be active whereas for female respondents, they sometimes active and also sometimes passive or just keep silent. One of the answers can be seen in the following part of the interview:

\section{Extract 4. Preferences of Activeness}

I: $\quad$ "then in an English class, for example, there is an activity, [do you] like to be active or just keep silent?"

M6: active

I: "what is the purpose?"

M6: "in order to know more" 


\section{I: $\quad$ (asking the female respondent) "how about you?" \\ F6: "sometimes active sometime silent"}

There is also a different tendency of male and female respondents in terms of their activeness in the class. From the session of interview above, it can be seen that both of the respondents above had different preferences whether to be active or to keep silent. The female respondent above stated that she was sometimes active and sometime passive whereas the male respondent chose to be active in order to know more. All of the male respondents stated that preference in the same way.

\section{DISCUSSIONS}

The result of the SILL above showed that there are different strategies used by male and female students in their learning strategies. Although there is no significant difference, female students use cognitive, compensation, and affective strategy more often compared to male students while male students use memory, metacognitive, and social strategy more often compared to female students.

Findings from this study shows that male and female students applied different learning strategies. A study by Jamiah et al (2015) had also found that male and female students chose different strategies of learning. The strategies selected by males were mostly compensation strategy while females preferred social strategy. Females students like discussing when learning English and they performed well in social thinking and interaction, which can be categorized as social strategy. Male students, on the other hand, were active in expressing their idea, logical and better in coordination, which is characterized as compensation strategy. Božinovi (2011) also found that the female sex more frequently use all types of learning strategies whereas Tam (2013) found a significant difference in using memory, compensation, cognitive, metacognitive, and social strategies to learn English, with females using all of these strategies more frequently than males.

The samples of the follow-up-interview conducted in this study with 12 respondents explained above also shows different characteristics of female and male students in English language teaching. In extract 1 and 2, respondents show their tendency to feel reluctant to speak due to some reasons such as being familiar and already in the same class and the same age. There are differences in the way to express opinions in which males preferred speaking whereas females preferred writing (extract 3). One of the prominent reasons is about the directness or the indirectness of their ideas they are talking about. Females in fact likes to be indirect and therefore, choose to express their ideas through writing, whereas males like to be direct and therefore chose speaking as the way to express their ideas. There are also differences in terms of preferences to be active and passive in the conversation in which males students tended to be active whereas females students might choose to be active and passive for some reasons (extract 4).

The result of this interview revealed the main characteristics of male and female students in their learning strategies and the reasons for the differences. Some of the reasons were due to male and female characteristics in communication. The reasons for choosing the strategy to learn such as ways of expressing opinion, being active or not, and the management of reluctance to speak could be influenced by gender differences.

This study proved that the notion of women's language (Lakoff $(1975,1976)$ \& Tannen $(1990,1994)$ influence the choices of learning strategies of male and female students in this study. The different style of communication of men and women as discussed in the notion of women's language lead the female and male students to choose their own strategies to learn. As revealed in the 
interview, female and male students have different preference of activeness/passiveness in studying English. They also have different ways of expressing opinions. Male respondents like to be active whereas for females their activeness will be influenced by many factors. Being active or passive for men and women also became a characteristics of men and women in communication which may influence their communicative performance.

These findings are also in line with previous studies. Tam (2013) states that gender is one important factor influencing the use of language learning strategies besides the second language proficiency and socioeconomic status. Wang (2009, p. 173) in her study had found the differences on male and female students on their learning strategies due to gender differences. She also suggested that teachers should teach students according to their aptitude and their preference of vocabulary learning strategies, their English proficiency, their majors and their genders. Oxford (1990) confirmed that due to maledominant social frameworks, males and females often adopt different communicative behavior, including in the way they learn. Based on Oxford taxonomy of learning strategies revealed through the SILL in this study, the strategies chosen by male students and female students are different.

Findings from this study emphasized that in a particular context of situation, male and female students might have different learning strategies. Based on the interview, gender differences can be an influencing factor, however, other factors such as familiarity and age differences may also influence. As revealed in this study, the learning strategies chosen by male and female students could be caused by their differences due to male and female characteristics. However, other factors may be influencing too. This is because these differences may be relative and influenced by other aspects. Therefore, teachers and students need to consider those differences and need to choose appropriate learning strategies.

\section{CONCLUSIONS}

Overall, it can be concluded that gender differences are an important aspect in English language teaching in Indonesia, particularly in senior high schools in Makassar. Students in the class are various and come from different backgrounds and therefore, they are different. Characteristics of men and women in communication can affect the performance of the Indonesian students in learning English. Those differences also open the possibilities of female and male students to be different in their learning strategy. Findings from this study prove that those different learning strategies can be caused by gender differences, particularly the notion of women's language (Lakoff, 1975, 1976; Tannen, 1990, 1994). Therefore, it is important for language learners to choose appropriate strategies. If gender factor is considered as one of the factors in choosing the appropriate learning strategies, this may result in good performance in learning.

Findings from this study bring significant contributions to the literature of gender differences in communication in a different setting of communication, that is in the classroom and English language teaching. It also gives beneficial input to the process of English language teaching at senior high schools in Makassar and in other cities in Indonesia. Findings from this study are also important information for language teachers in order to create good atmosphere in learning process. The phenomena experienced by the students revealed in this study indicated that in different settings of communication will bear different choices of learning strategies. In addition, factor of gender differences in the choices of those learning strategies need to be considered as a factor determining the success in English language teaching. 


\section{REFERENCES}

Ali, S. M. \& Krish, P. (2016). Gender-Specific English Language Use of Malaysian Blog Authors. Gema Online Journal of Language Studies, 16(3), 21-35.

Amir, Z., Abidin, H., Darus, S, \& Ismail, K. (2012). Gender differences in the language use of Malaysian teen bloggers. GEMA Online Journal of Language Studies, 12(1), 105-124

Anshori, D. S. (2016). Gender cognition in Religious Discourse: A Study of framing in thematic Holy Koran interpretation. Indonesian Journal of Applied Linguistic, 6(1), 88-98.

Azis, R. A., Jin, C. C., \& Nordin, N. M. (2016). The use of interactional metadiscourse in the construction of gender identities among Malaysian ESL learners. 3L: The Southeast Asian Journal of English Language Studies, 22(1), 207-220

Biber, D \& Burges, J. (2000). Historical change in the language use of women and men: Gender differences in dramatic dialogue. Journal of English Linguistics, 28(1), 21-37.

Božinovi, N. (2011). Gender differences in the use of learning strategies in adult foreign language learners. Dubrovnik, Croatia: American College of Management and Technology.

Burck, C. (2011). Living in several languages: Language, gender and identities. European Journal of Women's Studies, 18(4), $361-378$.

Cabaysa, C. C. (2010). Language learning strategies of students at different levels of speaking proficiency. Education Quarterly, 68(1), 16-35.

Earl-Novell, S. (2001). Gendered styles of writing and the inequality in assessment, hypothesis: An explanation for gender differentiation in first class academic achievement at university. The International Journal of Sociology and Social Policy, 21(1), 160-172.
Eckert, P \& McConnell-Ginet, S. (1994). Think practically and look locally: Language and gender as communitybased practice. In C. Roman, S. Juhasz, \& C. Miller (Eds.), The women and language debate, (pp. 432-460). New Brunswick, New Jersey: Rutgers University Press.

Ehrman, M., \& Oxford, R. L. (1989). Effects of sex differences, career choice, and psychological type on adult language learning strategies. Modern Language Journal, 73(1), 1-13.

Ellis, R. (1994). The study of second language acquisition. New York: Oxford University

Gay, L.R., Mills, G.E., \& Airasian, P. (2006). Educational research: Competencies for analysis \& application. Columbus: Charles E. Merrill Publishing Company.

Giles, H. (2008). Communication accommodation theory. In L.A. Baxter \& D. O. Braithwaite (Eds.), Engaging theories in interpersonal communication: Multiple perspectives (pp. 161-173). Thousand Oaks, SA, US: Sage Publication, Inc.

Gray, J. (1992). Men are from mars, women are from Venus: A practical guide for improving communication and getting what you want in your relationship. London: Thorsons.

Griffin, M.A., D. McGahee, \& J. Slate. (1999). Gender differences in nonverbal communication. Valdosta State University.

Gurian, M. (2001). Boys and girls learn differently!. San fransisco, ca: josseybass. Kato, s. How language learning strategies affect English proficiency in Japanese university students. Journal of the Faculty of Human Studies, 7(1), 239262.

Hassan, I. H. (2000). Language, gender, and power: Analysis of theme and topic management in Arabic conversational 
discourse. The Humanities and Social Science, 61, 591.

Hassan, R. (2017). Gaya dan Strategi Pembelajaran Bahasa Melayu dalam Kalangan Pelajar Perancis (Malay Language Learning Styles and Strategies among French Students). Gema Online Journal of Language Studies, 17(1), 125146.

Hassaskhah, J. \& Zamir, S. R. (2013). Gendered Teacher-Student Interactions in English Language Classrooms: A Case of Iranian College Context. SAGE Open, 1-2, 1-11.

Itakuro, H. \& Tsui, A.B. M. (2004). Gender and conversation dominance in Japanese conversation. Language in Society, 33(2), 223-248.

Jamiah, Mahmud, M., Muhayyang, M. (2015). Do female and male students learn differently? ELT Worldwide, 2(2), 110125.

Kato, S. (2005). How language learning strategies affect English proficiency in Japanese university students. Journal of the Faculty of Human Studies, 7(1), 239262.

Kato, S. (2009). The relationship of language learning strategies and personality on English proficiency in Japanese university students. The Journal of Asia TEFL, 6(1), 141-162.

Keeler, W. (1990). Speaking of gender in Java. In J. M. Atkinston \& S. Errington (Eds.). Power and difference: Gender in Island Southeast Asia (pp. 127-152). Stanford, California, Stanford University Press.

Keong, Y. C., Gill, S. K., Noorezam, M., \& Abdulrazaq, A. (2012). Gender Differences and Culture in English Short Message Service Language among Malay University Students. 3L: The Southeast Asian Journal of English Language Studies, 18(2), 67-74

Khmakhien, A. (2012). Demystifying Thai EFL Learners' Perceptual Learning Style
Preferences. 3L: The Southeast Asian Journal of English Language Studies, 18(1), 61-74.

Kobayashi, Y. (2014). Gender gap in the EFL classroom in East Asia. Applied Linguistics, 35(2), 219-223.

Koeser, S. \& Sczesny, S. (2014). Promoting Gender-Fair Language: The Impact of Arguments on Language Use, Attitudes, and Cognitions. Journal of Language and Social Psychology, 33(5), $548-560$

Kuipers, J. C. (1990). Talking about troubles: Gender differences in Wayéwa ritual speech use. In J. M. Atkinston \& S. Errington (Eds.). Power and difference: Gender in Island Southeast Asia (pp. 153-173). Stanford, California, Stanford University Press.

Krashen, S. (2013). Reading and vocabulary acquisition: Supporting evidence and some objections. Iranian Journal of Language Teaching Research, 1(1), 2743.

Lakoff, R. (1975). Language and woman's place. Language in Society, 2(1), 45-80. Cambridge University Press Stable URL: http://www.jstor.org/stable/4166707

Lakoff, R. T. (1976). Language and woman's place. New York: Octagon Books.

Lee, C. K. (2010). An overview of language learning strategies. Arecls, 7, 132-152.

Lee, J.F.K. \& Collins, P. (2008). Gender voices in Hong Kong English textbooks: Some past and current practices. Sex Roles, 59(1), 127-137.

Li, J. (2005). An empirical study on learning strategies of tertiary-level EFL learners in China. The Journal of Asia TEFL, 2(1), 131-154.

Logan, S \& Johnston, R. (2009). Gender differences in reading ability and attitude: examining where these differences lie. Journal of Research in Reading, 32(2), 129-214. 
Mahmud, M. (2008). Politeness in Bugis (Unpublished doctoral thesis). The Australian National University, Australia.

Mahmud, M. (2010). Language and gender in English language teaching. TEFLIN Journal, 21(2), 172-184.

Mahmud, M. (2015). Students' expectations toward their teachers: A study on teachers' competence, gender issues and politeness between teachers and students in Indonesian context. ELT Worldwide, 2(1), 96-112.

Mahmud, M. (2017). Communicative styles of English students at the State University of Makassar. GEMA Online Journal of Language Studies, 17(1), 223-238.

Mahmud, M. (2018). Exploring students' politeness perspectives at the State University of Makassar. Journal of Education and Learning, 12(1), 36-43.

Martin, A., \& Marsh, H. (2005). Motivating boys and motivating girls: Does teacher gender really make a difference? Australian Journal of Education, 49(3), 320-334.

Mellor, D. \& Fung, S.W.T. (2012). Forgiveness, empathy, and gender: A Malaysian perspective. Sex Roles, 67(98), 1-7.

Nasab, M.S.H., \& Motlagh, S.F.P. (2017). Male and female students' narrative similarities and differences in the advance levels in line with advance organizers. Communication and Linguistics Studies. Special Issue: Applied Linguistics in Line With TEFL, 3(1-1), 8-13. DOI: 10.11648/j.cls.s.2017030101.12

Oxford, R. (1989). Use of language learning strategies: A synthesis of studies with implications for teacher training. System, 17, 235-247.

Oxford, R. (1990). Language learning strategies: What every teacher should know. Boston: Heinle \& Heinle.
Oxford, R. L. \& Burry-Stock, J. (1995). Assessment the use of language learning strategies worldwide with the ESL/EFL version of the strategy inventory for language learning (SILL). System, 23(1), 1-23.

Oxford, R. L. (Ed.) (1996). Language learning strategies around the world: Crosscultural perspectives. Honolulu: University of Hawaii Press.

Oxford, R., \& Nyikos, M. (1989). Variables affecting choice of language learning strategies by university students. Modern Language Journal, 73, 166-174.

Park, G. \& French, B. F. (2011). Beyond the mean differences of the SILL by gender: Differential item functioning. The Journal of Asia TEFL, 8(4), 175-203.

Puteh, M., Zin, Z. M. \& Ismail, I. (2016). Reading Performance of Malaysian Students across Gender in PISA 2012. 3L: The Southeast Asian Journal of English Language Studies, 22(2), 109 121

Rahimi, M., \& Hosseini Karkami, F. (2015). The role of teachers' classroom discipline in their teaching effectiveness and students' language learning motivation and achievement: A path method. Iranian Journal of Language Teaching Research, 3(1), 57-82

Roohani, A. \& Zarei, M. (2013). Evaluating gender-bias in the Iranian pre-university English textbooks. Indonesian Journal of Applied Linguistics, 3(1), 115-125.

Sakurai, Y. (2012). Learners' perceptions of "good" foreign language teachers: A quantitative analysis between native and non-native teachers. Electronic Journal of Foreign Language Teaching, 9(1), 4660.

Seyyedrezaie, Z. S. \& Vahedi, V. S. (2017). Projecting gender identity through metadiscourse 
Marking: Investigating writers' stance taking in written discourse. Indonesian journal of Applied Linguistics, 6(2), 301-310

Serag, A. (2011). Teaching English writing skills: Developing learner autonomy in Japanese context. International Journal of Arts and Science, 4(10), 223-237.

Severiens, S \& Dam, G. (2005). Soodmand Afshar, H., \& Doosti M. (2014). Exploring the characteristics of effective Iranian EFL teachers from students' and teachers' perspectives. Iranian Journal of Applied Language Studies, 6(1), 205230.

Stanton, A. (2001). Men and women in conversation: Finding a way to bridge the gap, University of Massachusetts. http://www.healthandage.com/public/he alth-center/28/article/1284/Men-andWomen-in-Conversation-Finding-aWay.html. Accessed 10 July 2008.

Starbuck. (2003). College teaching styles by gender. Paper presented at Western Social Science Annual Meeting, April 912, 2003, Las Vegas, Nevada.

Tam, K. (2013). A study on language learning strategies (LLSs) of university students in Hong Kong (Unpublished Thesis). The University of Hong Kong.

Tannen, D. (1990). You just don't understand: Women and men in conversation. New York: Harper Collins.

Tannen, D. (1994). Gender and discourse. New York; Oxford: Oxford University Press.

Tymson, C. (1998). Gender games: Doing business with the opposite. Australia: Tymson Communication.

Vanfossen, B. (2001). Gender differences in communication. ITROW's Women and Expression Conference.

Viriya, C. \& Sapsirin, S. (2014). Gender differences in language learning style language learning strategies. Indonesian Journal of Applied Linguistics, 3(2), 7788. Retrieved on 22 September 2015.
From

http://ejournal.upi.edu/articl/download.

Wang, L. (2009). An empirical study of differences in the use of English vocabulary learning strategies. The Journal of Asia TEFL, 6(4), 151-192.

Yilmaz, C. (2010). The relationship between language learning strategies, gender, proficiency and self-efficacy beliefs: A study of ELT learners in Turkey. Procedia social \& Behavioral Science journal, 2(2), 682-687. Retrieved on 22 September $2015 . \quad$ From www.sciencedirect.com/aticle

Younger, M. Warrington, M. \& Jacquita, W. (1999). The gender gap and classroom interactions: Reality and rhetoric? British Journal of Socially of Education, 20(3).

Zhenhui, R. (2005). Gender, academic major, and Chinese students' use of language learning strategies: social and educational perspectives. The Journal of Asia TEFL, 2(3), 115-138. 